\title{
Early Post-Operative Results after Repair of Traumatic Brachial Plexus Palsy
}

\section{Travmatik Brakiyal Pleksus Palsisi Tamirinden Sonra Erken Postoperatif Sonuçlar}

Ahmad MOHAMMAD-REDA

Zagazig University, Department of General Surgery, Plastic and Reconstructive Unit, Zagazig, Egypt

Correspondence address: Ahmad MOHAMMAD-REDA / E-mail: mohammadelhanafy@yahoo.com

\begin{abstract}
AIM:Treatment options for traumatic brachial plexus injuries include nerve grafting, or neurotization. The type of lesion and the reconstructive procedures affect functional results and postoperative pain relief.

MATERIAL and METHODS: A total number of twenty five patients suffering from post-traumatic brachial plexus injury were included in the study. The patients underwent exploration and primary repair of the affected plexus, based on case by case policy.

RESULTS: Spinal accessory nerve transfer to suprascapular nerve procedure regained $78.95 \%$ of functional muscle power, $10.50 \%$ of non functional muscle power and only $10.5 \%$ of non innervated muscle. The Oberlin procedure regained $83.33 \%$ with elbow flexion muscle power, $16.67 \%$ with non functional muscle power. Intercostal nerve transfer to musculocutaneous nerve regained $62.5 \%$ with functional muscle power, $25 \%$ with non functional muscle power and only $12.5 \%$ with non innervated muscle. The shoulder, elbow and wrist extension functions were significantly improved early post-operatively. In addition, the post-operative improvement of shoulder, elbow and wrist extension functions had significant negative correlations with the pre-operative elapsed time, and accompanied by a significant positive correlation with post-operative follow up period.
\end{abstract}

CONCLUSION: Early intervention for traumatic brachial plexus palsy is recommended to get good results with pain relief.

KEYWORDS: Brachial plexus, Traumatic, Neurotization

öz

AMAÇ:Travmatik brakiyal pleksus yaralanmaları için tedavi seçenekleri arasında sinir grefti veya nörotizasyon vardır. Lezyon tipi ve rekonstrüktif işlemler işlevsel sonuçları ve postoperatif ağrı kesilmesini etkiler.

YÖNTEM ve GEREÇLER: Bu çalışmaya posttravmatik brakiyal pleksus yaralanması olan toplam yirmi beş hasta dahil edildi. Her vakanın durumuna göre karar verilerek hastalarda etkilenen pleksusta eksplorasyon ve primer tamir yapıldı.

BULGULAR: Supraskapular sinire spinal aksesuar sinir transferi \%78,95 işlevsel kas gücü, \%10,50 işlevsel olmayan kas gücü ve sadece $\% 10,5$ innerve olmayan kas kazandırdı. Oberlin işlemi \%83,33 dirsek fleksiyonu kas gücü ve \%16,67 işlevsel olmayan kas gücü kazandırdı. Müskülokütanöz sinire interkostal sinir transferi $\% 62,5$ işlevsel kas gücü, $\% 25$ işlevsel olmayan kas gücü ve sadece\%12,55 innerve olmayan kas kazandırdı. Omuz, dirsek ve bilek ekstansiyon işlevleri postoperatif erken dönemde önemli ölçüde düzeldi. Ayrıca, omuz, dirsek ve bilek ekstansiyon işlevlerinin postoperatif düzelmesinin preoperatif geçen süreyle önemli bir negatif korelasyonu bulundu ve postoperatif takip dönemiyle önemli bir pozitif korelasyonu vardı.

SONUÇ: Travmatik brakiyal pleksus palsisinde ağrı giderilmesiyle birlikte iyi sonuçlar alınması için erken girişim önerilir.

ANAHTAR SÖZCÜKLER: Brakiyal pleksus, Travmatik, Nörotizasyon

\section{INTRODUCTION}

The improved modern-day outcome of brachial plexus reconstruction, even with severe degrees of palsies involving root avulsions, is a result of many factors: first, the advent of microsurgical techniques, second, better understanding of the nature of brachial plexus injuries and third, the extensive research on surgical techniques (41).

The application of microsurgical techniques and the establishment of the principle of tension free repair in peripheral nerve surgery, brought several new techniques for brachial plexus reconstruction, especially in supraclavicular lesions with multiple avulsions (40). A variety of extraplexus donors has been introduced to neurotize selected muscles in order to achieve essential function in the shoulder, elbow and hand (36).

In 1961 Yeoman and Seddon (45) advocated neurotization of the musculocutaneous nerve with intercostal nerve transfer. Then other nerve transfers were used such as the contralateral lateral pectoral nerve, spinal accessory nerve, the hypoglossal nerve, phrenic nerve, contralateral $C 7$, and selective ulnar 
nerve $(3,11,19,23,24)$. The best outcome of neurotization can be expected in short denervation times and in the presence of proximal healthy roots (4). Moreover, neurotizations using unavulsed roots are superior to utilization of extraplexus donors (7).

Surgery is indicated in closed lesions leading to traumatic brachial plexus palsy, with no improvement after 3 months. Surgery consists of the repair of affected nerves if possible, and if the nerves have been avulsed peripheral neuritization is indicated $(14,22)$.

Recently, indications for peripheral neuritization have been expanded to high-level nerve injuries with extensive gap for grafting and delayed nerve repairs (44), as well as to major bony or vascular injuries in the region of direct repair and previously failed proximal nerve repair (1). The main advantage of this procedure over classical nerve grafting is a conversion of proximal high-level injury to a low-level (44).

The aim of the present study was to assess the early results and prognostic values of the surgical treatments of traumatic brachial plexus on both functions and associated pain.

\section{PATIENTS and METHODS}

From March 2008 to July 2011, a total number of twenty five patients suffering from post traumatic brachial plexus injury were presented in general surgery department, plastic surgery unit in Zagazig University Hospital. This study emphasized the evaluation of shoulder, elbow, and wrist extension because the early postoperative results occurred in these parts. Some of the patients ( 6 patients) had presented clinically with zero shoulder function and zero elbow functions (upper brachial plexus palsy; (5 and (6), and others had clinically presented with zero shoulder function, zero elbow functions and no wrist extension (19 patients: 14 of them had total brachial plexus palsy and 5 of them had upper brachial plexus palsy; C5, 6 and C7) (Table I).

Patient age ranged from 10 to 51 yeas with main value of $( \pm S D$ ) of $25 \pm 13.26$ ( 20 males and 5 females). The time elapsed before surgery was ranged from 3 to 24 months with main value of $6.32 \pm 4.22$ months.

Patients provided consent after explanation of the surgical techniques and the expected results. The study design was approved by the research ethics committee of the faculty of medicine, Zagazig University.

Detailed neurological and functional evaluation including muscular strength, and pain were done (Figure $13 \mathrm{~A}-\mathrm{C}$ ). Muscular strength was recorded according to British Medical Research Council (BMRC) grading $(10,33,45)$ (Table II).

Table I: Traumatic Brachial Plexus Lesions and the Procedures Used for the Twenty Five Patients

\begin{tabular}{|c|c|c|}
\hline Cases & Lesion & Procedure \\
\hline 3 & Rupture of $C 5-6$ roots. & $\begin{array}{l}\text { Spinal accessory transfer to suprascapular nerve. Repair of upper trunk } \\
\text { from C5 \& middle trunk from C6. }\end{array}$ \\
\hline 2 & Rupture of $C 5-6$ roots. & $\begin{array}{l}\text { Spinal accessory transfer to suprascapular nerve. Repair of upper trunk } \\
\text { from C5 \& middle trunk from C6. Motor fascicle from redial nerve to axillary } \\
\text { nerve }\end{array}$ \\
\hline 2 & Rupture of $C 5-6$ roots \& avulsion of $C 7$. & $\begin{array}{l}\text { Spinal accessory transfer to suprascapular nerve, Oberlin (motor fascicle } \\
\text { from ulnar nerve to musculocutaneous nerve). }\end{array}$ \\
\hline 2 & Rupture of C5-6 roots. & $\begin{array}{l}\text { Spinal accessory transfer to suprascapular nerve, Oberlin procedure. Repair } \\
\text { of upper trunk from C5 \& middle trunk from C6. }\end{array}$ \\
\hline 2 & Rupture of $C 5-6$ roots & Plexo-plexal repair using cable nerve grafts. \\
\hline 2 & Rupture of $C 5-6$ roots. & Oberlin procedure. \\
\hline 2 & $\begin{array}{l}\text { Rupture of } \text { C5- roots. } \\
\text { C6-7-8, T1 avulsion, }\end{array}$ & $\begin{array}{l}\text { Spinal accessory transfer to suprascapular nerve, intercostal nerves transfer } \\
\text { to musculocutaneous nerve. Repair of lower trunk from C5. }\end{array}$ \\
\hline 2 & Rupture of all cords. & Interposition Sural grafts, subclavein artery \& vein grafting, \\
\hline 2 & Avulsion of all roots & $\begin{array}{l}\text { Spinal accessory transfer to suprascapular nerve, intercostal nerves transfer } \\
\text { to musculocutaneous nerve. }\end{array}$ \\
\hline 2 & $\begin{array}{l}\text { Rupture of } C 5-6 \text { roots avulsion of } \\
\text { C 7-8 \& } 11\end{array}$ & $\begin{array}{l}\text { Spinal accessory transfer to suprascapular nerve, intercostal nerves transfer } \\
\text { to musculocutaneous nerve, Repair of middel trunk from C5 \& lower trunk } \\
\text { from C6. }\end{array}$ \\
\hline 2 & $\begin{array}{l}\text { Rupture of } C 5-6 \text { roots avulsion of } \\
\text { C 7-8 \& } 1\end{array}$ & $\begin{array}{l}\text { Spinal accessory transfer to suprascapular nerve, Repair of upper trunk } \\
\text { from C5 \& middle trunk from C6. }\end{array}$ \\
\hline 2 & $\begin{array}{l}\text { Rupture of } C 5 \text { root avulsion of } \\
\text { C 6-8 \& T } 1\end{array}$ & $\begin{array}{l}\text { Spinal accessory to suprascapular nerve, intercostal nerves to } \\
\text { musculocutaneous nerve, cross } C 7 \text { to lower trunk. }\end{array}$ \\
\hline
\end{tabular}


Table II: BMRC Grading of Muscle Power

\begin{tabular}{|c|c|c|}
\hline Grade & Muscle power & Function \\
\hline 0 & No contraction & Non innervated \\
\hline 1 & $\begin{array}{l}\text { Palpable but not visible } \\
\text { contraction }\end{array}$ & Non functional \\
\hline 2 & $\begin{array}{l}\text { Movement when gravity has } \\
\text { been excluded }\end{array}$ & Non functional \\
\hline 3 & Movement against gravity & functional \\
\hline 4 & Movement against resistance & functional \\
\hline 5 & Normal muscle power & functional \\
\hline
\end{tabular}

Pain was described in terms of its time of onset, site, radiation, and relief with medication (12); Degree 0 indicated no pain, degree 1 indicated intermittent pain that related usually to the weather or to the patient's emotional state, degree 2 denoted severe pain, and degree 3 expressed intolerable pain that was sufficient to awaken the patient from sleep and could not be relieved by major analgesics (5).

All patients were operated by exploration and repair of the brachial plexus. Different types of reconstruction were conducted, the choice of procedure being made on a case by-case basis. The post-operative follow up periods with physiotherapy ranged from 6 to 36 months with a mean value of $18.88 \pm 8.22$ months.

Surgery was executed under general anesthesia in supine position and without usage of muscle relaxants. A zigzag skin incision was used in some of the cases: a supraclavicular incision and an infraclavicular incision (21) (Figure 1).

A $15-\mathrm{cm}$ necklace incision $(9,28)$ situated $1 \mathrm{~cm}$ above and parallel to the clavicle was used in other patients to expose the supraclavicular plexus (Figure 2). Division of the platysma allows supraclavicular nerves identification and preservation (Figure 3). The infraclavicular part of the plexus was explored through the deltopectoral incision.

The phrenic nerve was identified over the surface of the anterior scalenus muscle, and the spinal accessory nerve was detected at the medial border of the trapezius muscle.

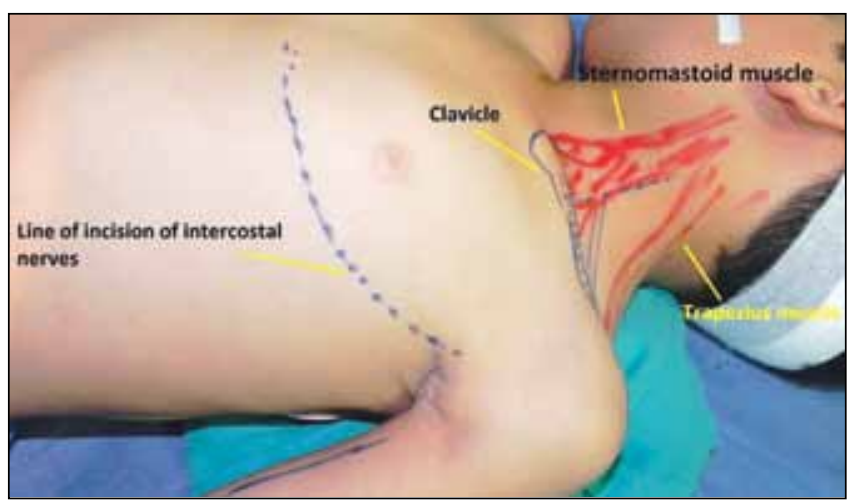

Figure 1: Drawing for classical incision of supraclavicular area and incision for intercostal nerves.
The $C 5, C 6, C 7$ nerve roots were found at the lateral border of the anterior scalenus muscle (Figure 4). The same route was employed for identification of the anterior and posterior division of the upper trunk and the suprascapular nerve.

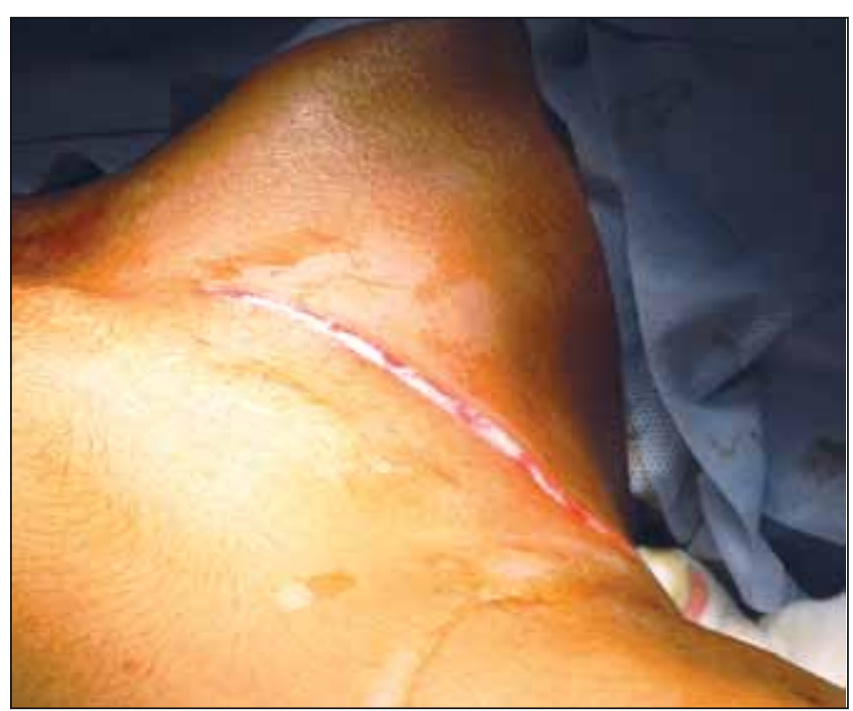

Figure 2: Supraclavicular transverse incision.

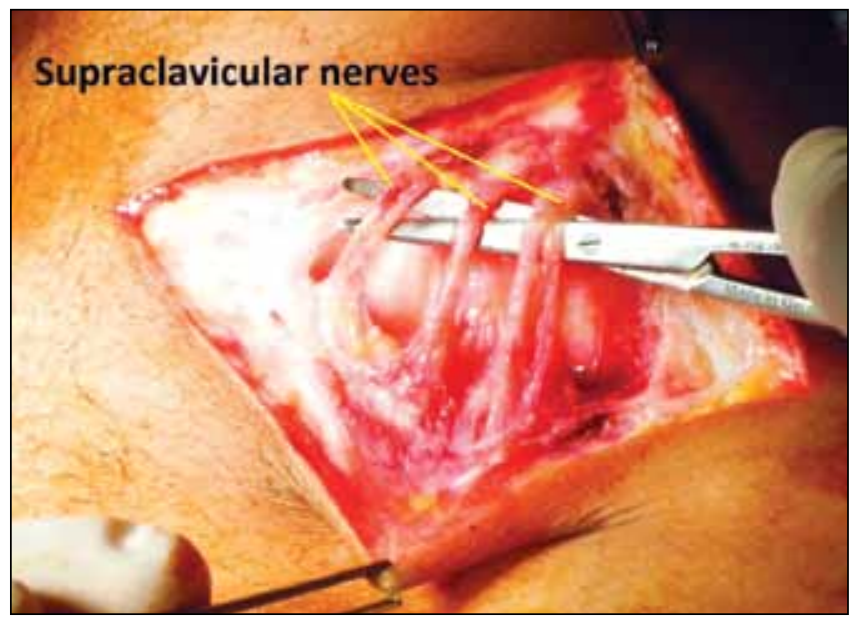

Figure 3: Supraclavicular nerves.

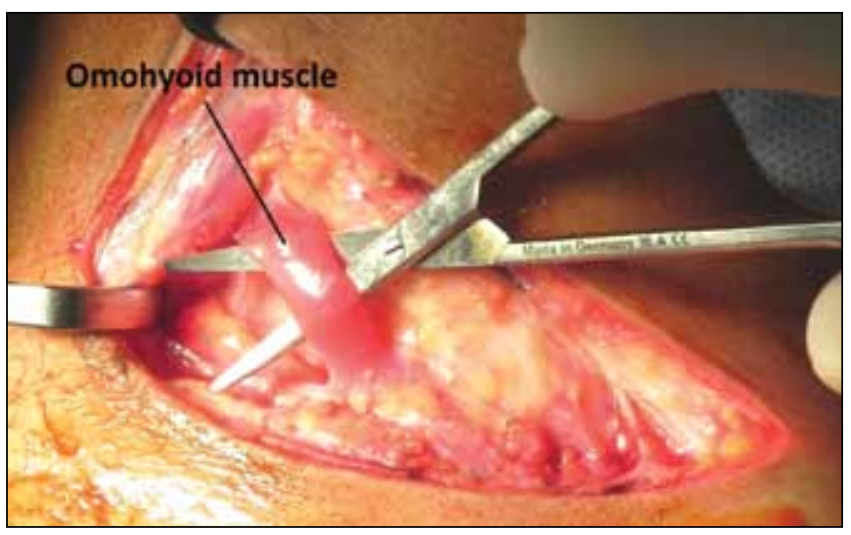

Figure 4: Omohyoid muscle dissection. 
The infraclavicular brachial plexus was reached via a deltopectoral incision with a section of the pectoralis minor muscle. Following mobilization of the musculocutaneous nerve and retraction medially of the lateral cord and the axillary artery, the radial nerve was detected at the point where it passed superficial to the lower border of the subscapularis muscle.

According to Socolovsky et al. (35), plexoplexal repair with cable nerve grafts (Figure 5) was performed if there was root rupture and the treatment strategy included reanimation of the suprascapular and musculocutaneous nerve in most of the patients.

After confirmation of avulsion nature of the injury, neuritization by extraplexus source was the only solution.

In nineteen patients reinnervation of the suprascapular nerve was done by spinal accessory (Figure 6). After stimulation of the spinal accessory nerve by nerve stimulator, the nerve was transected distal to the last branch of the three supling trapezius. The proximal stump was then sutured to the distal stump of suprascapular nerve with $10 / 0$ prolene or nylon sutures under surgical microscope magnification, or glued by fibrin glue. The reinnervation of musculocutaenous nerve was done through different methods. In this study if lower roots $\mathrm{C} 8, \mathrm{~T} 1$ were intact, Oberlin procedure was the best choice (Figure 7): A longitudinal incision was made along

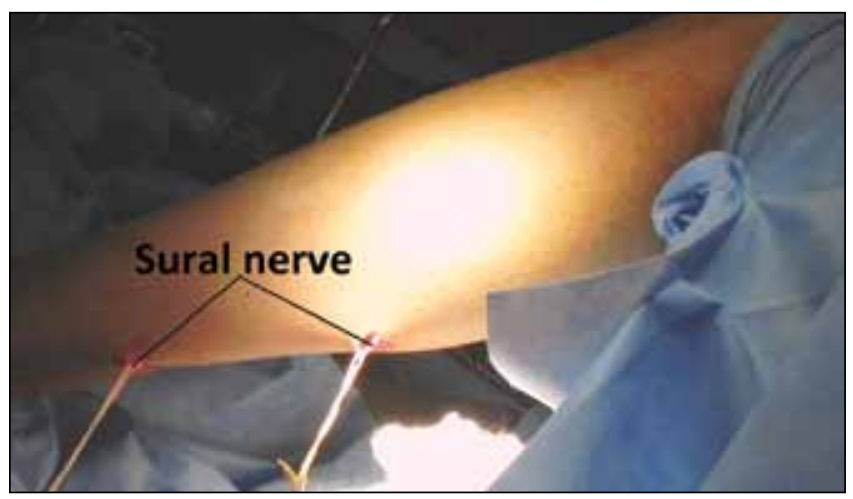

Figure 5: Multiple stapes for sural nerve harvesting.

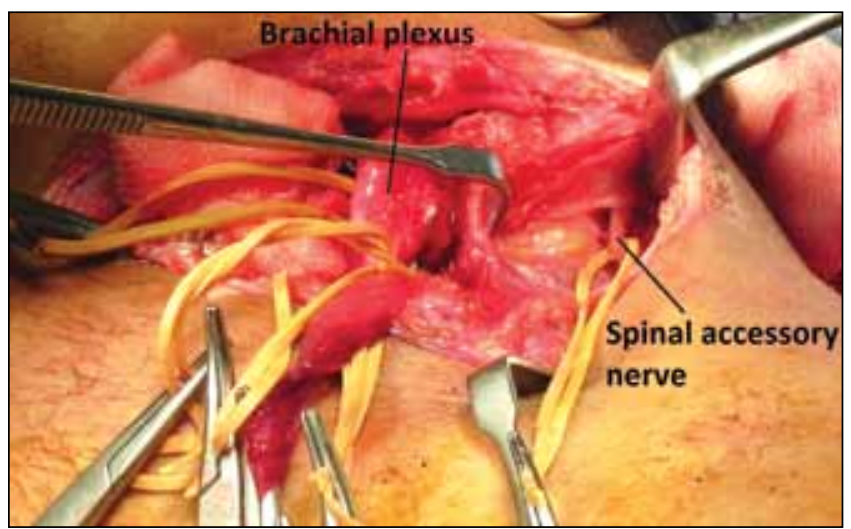

Figure 6: Exploration of the spinal accessory nerve. the upper medial surface of the arm and the ulnar nerve was explored and detected by the use of a nerve stimulator. The epineurium was opened and the fascicles were exposed. The posteromedial fascicle containing muscular fibers to flexor carpi ulnaris was carefully isolated and transected.

The musculocutaneous nerve was detected between the coracobrachialis and biceps brachii muscles (Figure 11), and followed by dissection to the point in which a muscular branch enters the biceps brachii. This fascicle was transected sharply and sutured to the ulnar nerve fascicle, again under microscope magnification and by prolene 10/0 sutures, or Nylon, or glued by fibrin glue.

In total traumatic patients, the Intercostal nerves were used to reinnervate musculocutaenous (Figure 8); they are harvested via a thoracic exposure and subperiosteal dissection along the inferior surface of the ribs. A long incision beginning high in the axilla and running inferiorly then curved beneath the ipsilateral nipple, corresponding to the inferior margin of the fifth rib.

The pectoralis major muscle is reflected medially and superiorly (Figure 9). Electrocautery is used to open the periosteal sleeve, and a periosteal elevator used to dissect the periosteum from the internal surface of the rib (Figure 10). Sharp

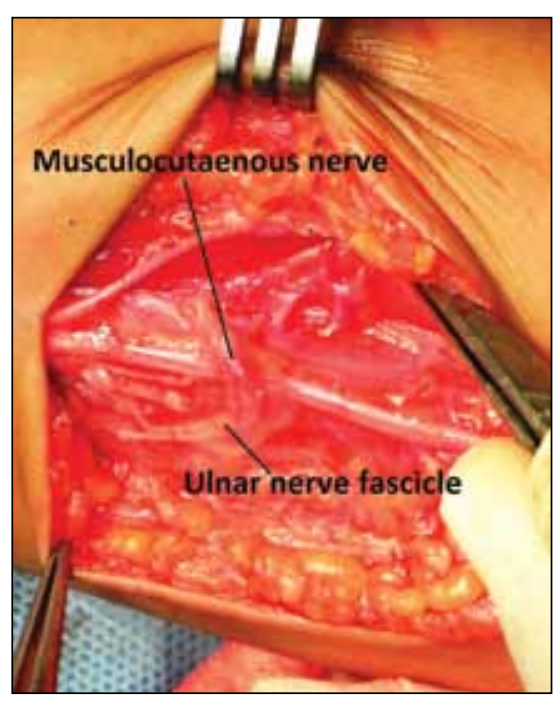

Figure 7: Oberlin procedure (motor fascicle of ulnar nerve to musculocutaneous nerve.

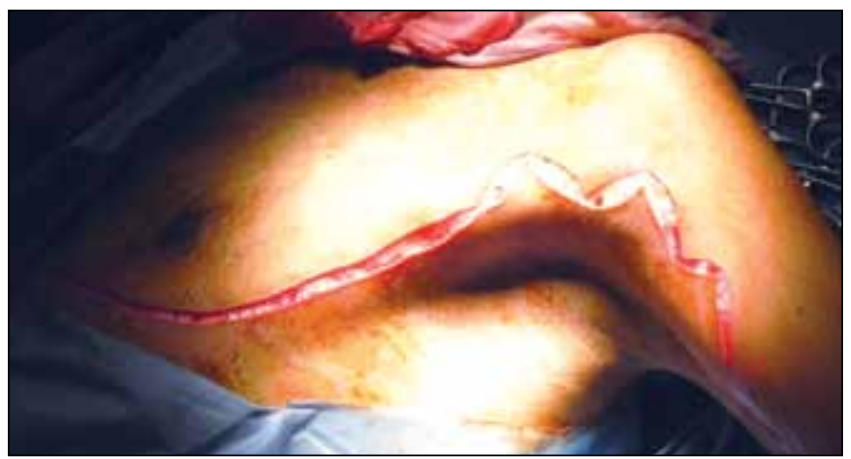

Figure 8: Incision for intercostal nerves retrival. 


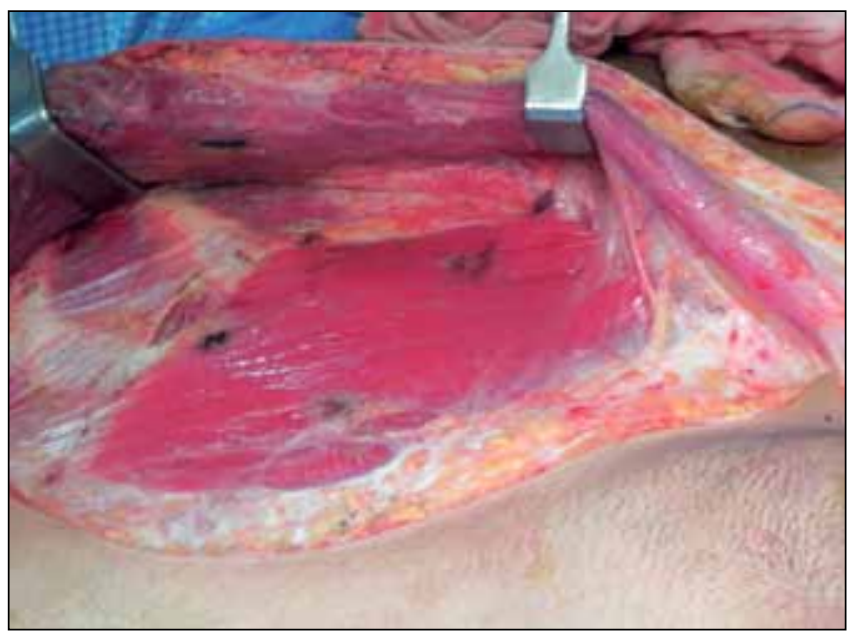

Figure 9: Elevating of pectoralis major muscle.

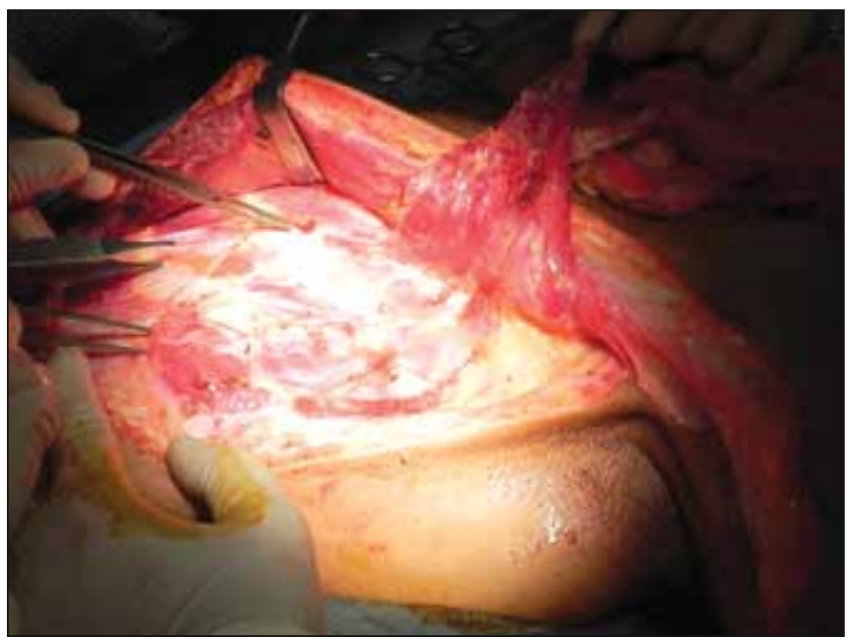

Figure 10: Elevation of pectoralis minor muscle.

dissection through the periosteum identified the intercostal nerve and intimately associated artery; great care should be used so as not to perforate the pleura, which lies immediately deep to the nerves (32) (Figure 12).

The affected upper extremity was immobilized in a sling for 3 weeks, with the elbow flexed at $90^{\circ}$. This process was followed by intense physiotherapy training: initially, passive elbow extension exercises were encouraged to prevent joint contractures.

\section{Statistical analysis:}

Statistical analysis was performed using the 18.0 version of SPSS statistical software for windows. The unpaired Student $t$ test was used in the comparison between pre- and post-operative shoulder functions, elbow functions, wrist extension functions and pain. Pearson correlation was used between age, pre-operative period and follow up period with each of post-operative pain, shoulder functions, elbow functions and wrist extension functions. $P$ values less than 0.05 were considered significant.

\section{RESULTS}

Various procedures were used in this study; one of the most common procedures was spinal accessory nerve transfer to the suprascapular nerve and muscle grading revealed $78.95 \%$ (15/19 patients) regaining functional muscle power (M5M3), $10.50 \%$ (2/19 patients) regaining non functional muscle power (M1-M2) and only $10.5 \%$ (2/19 patients) with non innervated muscle (M0).

For the Oberlin procedure, the other common procedure, the muscle grading showed $83.33 \%$ (5/6 patients) regaining functional muscle power (M5-M3), 16.67\% (1/6 patients) regaining non functional muscle power (M1-M2) and no cases with non innervated muscle.

As regards intercostal nerve transfer to the musculocutaneous nerve, muscle grading revealed $62.5 \%$ (5/8 patients) regaining functional muscle power (M5-M3), 25.0\% (2/8 patients)

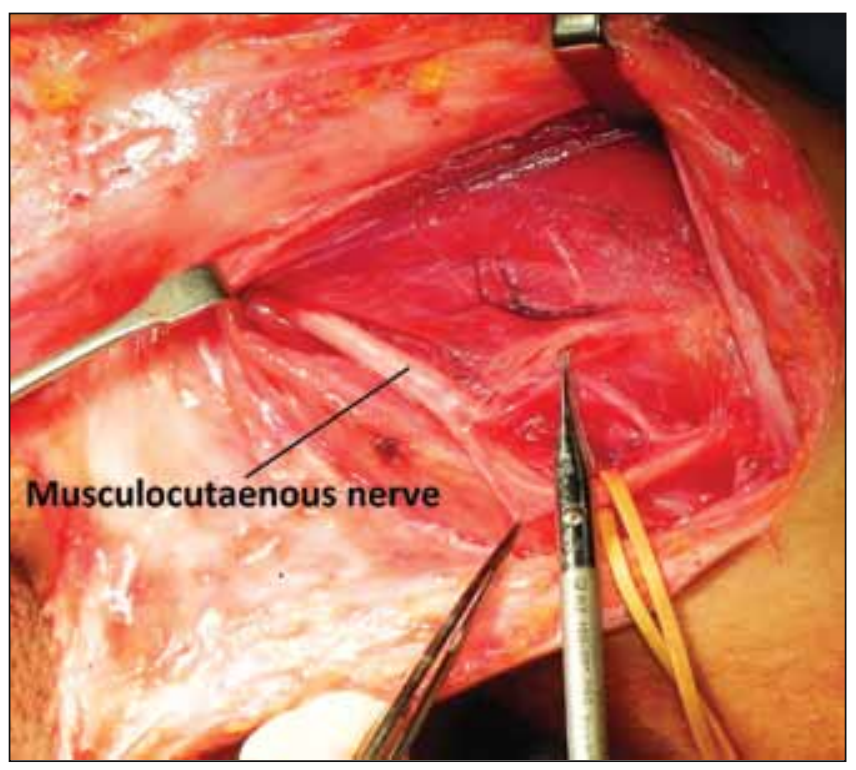

Figure 11: Musculocutaenous nerve exploration.

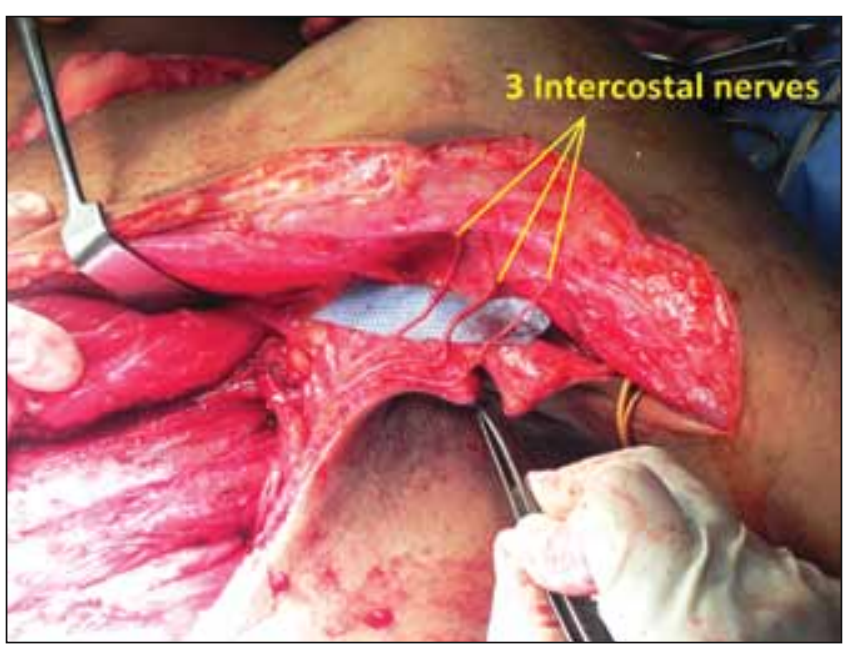

Figure 12: Three intercostal nerves ready for neuritization. 
regaining non functional muscle power (M1-M2) and only $12.5 \%$ (1/8 patients) with non innervated muscle (M0).

In general, the shoulder, elbow and wrist extension functions were significantly improved early post-operatively $(P<0.001)$. In addition, the post-operative improvement of shoulder, elbow and wrist extension functions had significant negative correlations with the pre-operative elapsed time $(P<0.05, P$ $<0.01 \& P<0.05$ respectively), accompanied by a significant positive correlation with post-operative follow up period $(\mathrm{P}<0.05)$ (Figure $14 \mathrm{~A}-\mathrm{C}$, Table III). However, no significant correlations were noticed between improvement and age of patients $(P>0.05)$. While, the post-operative pain severity correlated negatively with the age of patients and follow up periods, it had no correlation with pre-operative periods.

\section{DISCUSSION}

Different methods of repair have been described in attempts to regain mobility and sensation, especially for the proximal parts of the affected limb (shoulder and elbow) (2).

In the present study, early results of spinal accessory nerve transfer to suprascapular nerve procedure regained $78.95 \%$ of functional shoulder muscle power (M5-M3), $10.50 \%$ of non functional muscle power (M2-M1) and only $10.5 \%$ of non innervated muscle (M0).
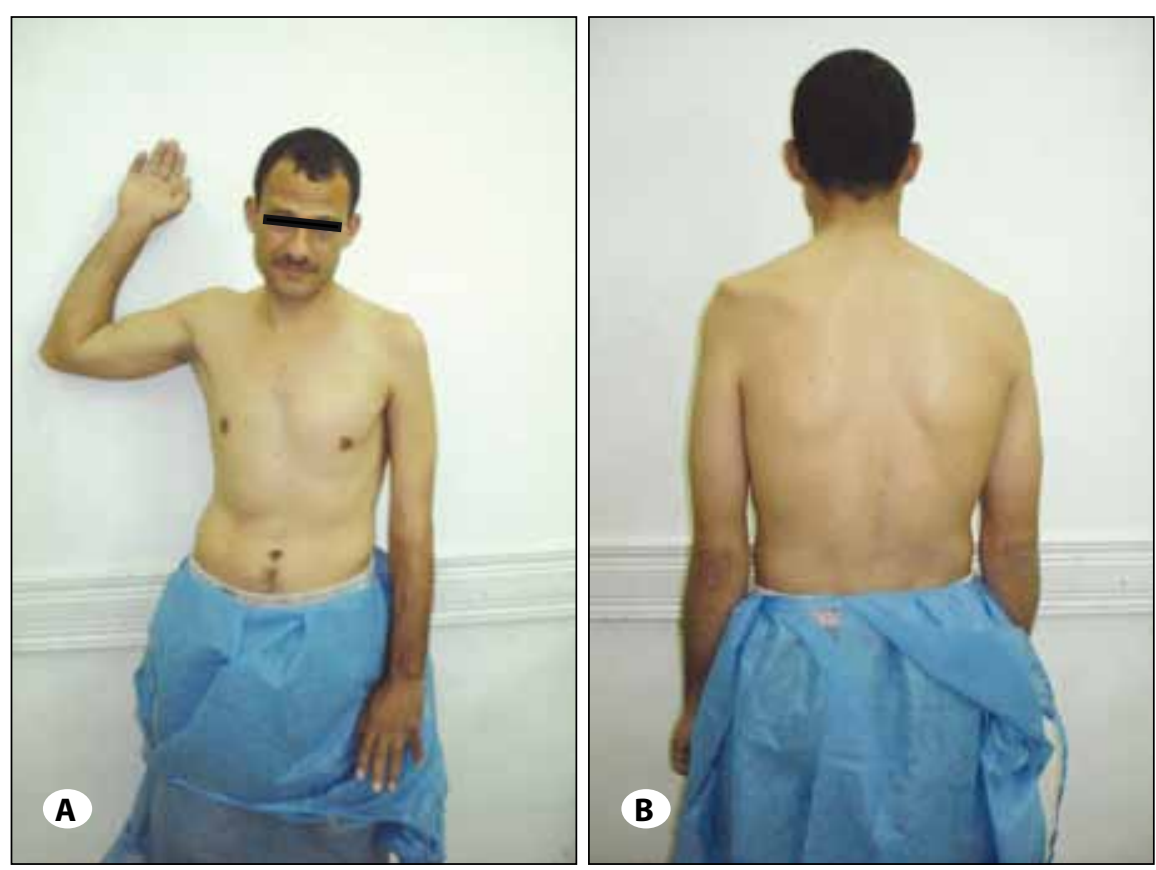

Figure 13A-C: Preoperative.

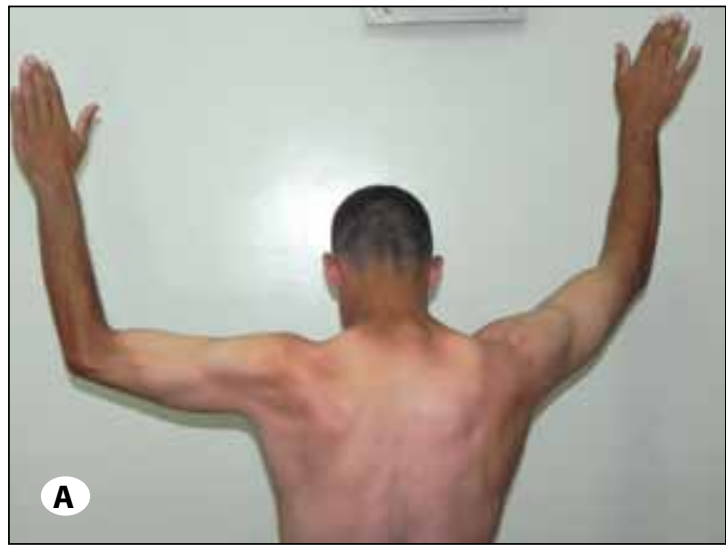

Figure 14A-C: Postoperative.
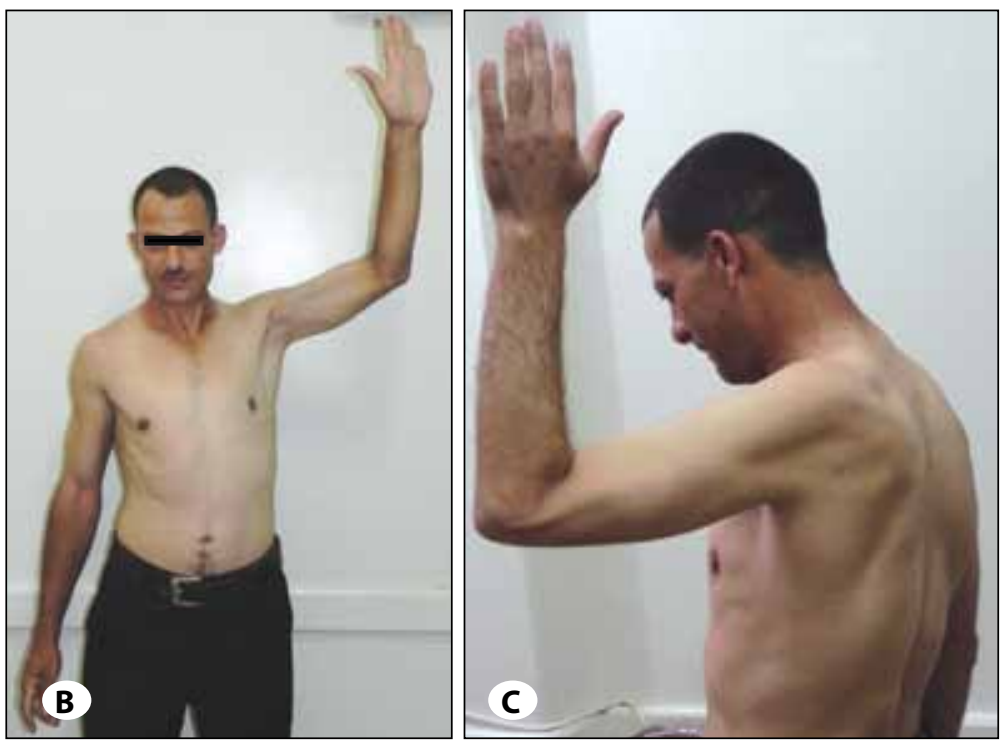
Table III: Shoulder, Elbow and Wrist Extension Functions Improvement and Its Correlations to Age, Pre-Operative Elapsed Time and Post-Operative Follow Up Periods of all Procedures

\begin{tabular}{|l|c|c|c|c|c|}
\hline \multirow{2}{*}{ Item } & Before surgery & After surgery & \multicolumn{4}{|c|}{ Pearson correlation $(\mathbf{r})$ with } \\
\cline { 5 - 6 } & (Mean \pm SD) & $($ Mean \pm SD) & Age & pre-operative period & Follow up period \\
\hline Shoulder & $0.00 \pm 0.00$ & $3.00 \pm 1.68^{* * *}$ & $-0.276^{\mathrm{NS}}$ & $-0.428^{*}$ & $+0.440^{*}$ \\
\hline Wrist Ex & $0.00 \pm 0.00$ & $3.20 \pm 1.60^{* * *}$ & $-0.331^{\mathrm{NS}}$ & $-0.538^{* *}$ & $+0.412^{*}$ \\
\hline Pain severity & $0.00 \pm 0.00$ & $1.44 \pm 1.38^{* * *}$ & $-0.229^{\mathrm{NS}}$ & $-0.412^{*}$ & $+0.493^{*}$ \\
\hline
\end{tabular}

NS (non significant) $=\mathrm{P}>0.05,{ }^{*}=\mathrm{P}<0.05,{ }^{* *}=\mathrm{P}<0.01,{ }^{* * * *}=\mathrm{P}<0.001$.

The present results are in line with that of Terzis and Kostas (42) who reported that the spinal accessory to suprascapular nerve transfer was better than nerve transfer to the axillary nerve. In addition, Terzis and Papakonstantinou (40) reported excellent recovery of shoulder abduction (grade 3 or more) in $79 \%$ of the patients and in 55\% of the patients for external rotation. Bertelli and Ghizoni (6) achieved an average range of arm abduction up to 122 degrees, and external rotation up to 118 degrees in patients with upper lesion of the roots. Venkatramani et al. (43) obtained somewhat lower ranges with 66 degrees for arm abduction and 44 degrees for external rotation. Suzuki et al. (39) obtained similar average shoulder abduction of 77.1 degrees, but shoulder external rotation was far lower with only 16.7 degrees.

Malessy et al. (26) however reported that the reinnervation of the shoulder in patients with upper brachial plexus palsy following the suprascapular nerve neurotization is disappointingly low.

Probably the best solution is dual-nerve transfer to both the suprascapular and axillary nerves (1). Two of the nineteen patients in this study had this policy with satisfactory results.

It is fact that the first priorities in brachial plexus repair are restoration of full range and strong elbow flexion, shoulder stability, active arm abduction, and some external rotation (37). The improvement of all functions is equally important since these enable elbow movements through a more functional range (29).

In the present study, early results of Oberlin procedure (neurotization of the musculocutaneous nerve) revealed $83.33 \%$ of elbow functional muscle power (M5-M3), $16.67 \%$ of non functional muscle power (M2-M1). In addition, the intercostal nerves transfer to musculocutaneous nerve, revealed $62.5 \%$ elbow functional muscle power (M5-M3), $25.0 \%$ of non functional muscle power (M2-M1) and only 12.5 $\%$ of non innervated muscle (M0).

The restoration of elbow flexion may be achieved through reinnervation of the musculocutaneous nerve (27). excellent results achieved when accompanied by reinnervation of the suprascapular nerve since the supra- and infrascapular muscles are important for initiation of the active arm abduction and some external rotation.
In 2005, Mackinnon et al. (25) reported M4 or better strength of elbow flexion in six patients in the series with dual transfers for elbow flexion.

Early results of elbow flexion restoration by Chuang et al. (15) using intercostal transfer to the musculocutaneous nerve demonstrated $66 \%$ success. Chuang (13) reported an average of $80 \%$ success (M 3 ).

Nerve transfers using collateral branches of the brachial plexus constitute a distal form of the intraplexal nerve transfer that generally yields better results because of the higher number of motor fibers and more physiologic reconstruction. Furthermore, they offer some advantages to the classic intraplexal transfer, such as insignificant axonal mixing, absence of mass or cross innervation, anastomosis close to the target muscle, and more precise evaluation of donor nerve functional validity compared to that of the proximal nerve stumps (33).

Early results for elbow flexion, published by Oberlin in the mid 1990s, have convinced a significant number of surgeons to adopt distal transfers as a very successful technique (30).

One of the main advantages of distal procedures, besides the short distance to the target muscle, is the selective orientation of the growing axons toward the desired target nerve. This advantage is not present when the graft is short and directed towards a more proximal target like the anterior division of the upper trunk, which could cause some of the growing axons intended to follow elbow flexors to 'get lost' and be directed towards other motor or sensory targets (35).

In the present study, the post-operative improvement of shoulder, elbow and wrist extension functions had significant negative correlations with the pre-operative elapsed time ( $P$ $<0.05, \mathrm{P}<0.01 \& \mathrm{P}<0.05$ respectively). So the shorter the preoperative time delay the better the results.

The negative effect of time delay from trauma to surgery in brachial plexus reconstruction is reflected unanimously in the literature. The mean time from trauma to surgery in the group of responders was almost half that of non-responders, a difference that was highly statistically significant $(18,23)$. Jivan et al.(23) suspected that time to surgery may be an even stronger predictor of outcomes with long grafts, possibly because of particular features of this technique, including 
distal neurorrhaphy site fibrosis that could impede the growing axon as it strives to pass through on its way to the target end organ.

In this study, the close follow up and intense regimen of rehabilitation physiotherapy revealed a significant positive correlation between the follow up period and muscle functions improvement $(P<0.05)$.

The importance of an intense and prolonged rehabilitation program on the final result of a brachial plexus injury is well known at many centers $(8,12,20,21)$.

Despite the encouraging results with intercostal nerve transfer, greater functional success has been achieved by transferring intact branches of the ulnar or median nerves directly to the motor branches of the biceps and/or brachialis. Early results demonstrated 75 to $100 \%$ of patients achieved antigravity (M3) biceps strength or better, and recent results show between 75 and $94 \%$ M4 strength $(31,38)$. So I sticked in dealing with the patients to use intercostal nerve transfer only when there were no possiblility for oberlin procedure.

In conclusion, early intervention for traumatic brachial plexus palsy is highly recommended to get better results of motor function and pain relieve. The Oberlin procedure for elbow flexion restoration is preferable. Spinal accessory nerve transfer to suprascapular nerve is a good routine technique for shoulder function restoration.

\section{REFERENCES}

1. Addas $B$, Midha R: Nerve transfer for shoulder reanimation. In: Midha R, Zager E (eds) Surgery of Peripheral Nerves. New York: Thieme, 2008: 53-59

2. Allieu Y, Cenac P: Neurotization via the spinal accessory nerve in complete paralysis due to multiple avulsion injuries of the brachial plexus. Clin Orthop Relat Res 237:67-74, 1988

3. Allieu Y, Privat JM, Bonnel F: Paralysis in root avulsion of the brachial plexus: Neurotization by the spinal accessory nerve. Clin Plast Surg 11:133-137, 1984

4. Bentolila V, Nizard R, Bizot P, Sedel L: Complete traumatic brachial plexus palsy: Treatment and outcome after repair. J Bone Joint Surg 81:20-28, 1999

5. Berman J, Anand P, Chen L, Taggart M, Birch R: Pain relief from preganglionic injury to the brachial plexus by late intercostal transfer. J Bone Joint Surg 78:986-992, 1996

6. Bertelli J, Ghizoni M: Transfer of the accessory nerve to the suprascapular nerve in brachial plexus reconstruction. J Hand Surg (Am) 32:989-998, 2007

7. Bertelli JA, Ghizoni MF: Reconstruction of complete palsies of the adult brachial plexus by root grafting using long grafts and nerve transfers to target nerves. J Hand Surg (Am) 35:1640-1646, 2010

8. Birch R: Brachial plexus injury: The London experience with supraclavicular traction lesions. Neurosurg Clin N Am 20: 15-23, 2009
9. Birch R, Bonney G, Wynn Parry CB: Traumatic lesions of the brachial plexus. In: Birch R, Bonney G, Wynn Parry CB: Surgical Disorders of the Peripheral Nerves. Hong Kong: Churchill Livingstone, 1998:175-177

10. Brooks DM: Peripheral nerve injuries. Medical Research Council Special Report Series HMSO 418-429, 1954

11. Brunelli, G: Neurotization of avulsed roots of the brachial plexus by means of anterior nerves of the brachial plexus. Int J Microsurg 2:55-62, 1980

12. Chalidapong P, Sananpanich K, Klaphajone J: Electromyographic comparison of various exercises to improve elbow flexion following intercostal nerve transfer. J Bone Joint Surg 88:620-622, 2006

13. Chuang DC: Nerve transfers in adult brachial plexus injuries: My methods. Hand Clin 21:71-82, 2005

14. Chuang DCC: Adult brachial plexus injuries. In: Mathes SJ (ed) Plastic Surgery, 2nd ed. Philadelphia: Saunders, 2006: 515-538

15. Chuang DCC, Yeh MC, Wei FC: Intercostal nerve transfer of the musculocutaneous nerve in avulsed brachial plexus injuries evaluation of 66 patients. J Hand Surg (Am) 17A:822-828, 1992

16. Chuang D: Neurotization procedures for brachial plexus injuries. Hand Clin 11:633-639, 1995

17. Daneyemez M, Solmaz I, Izci Y: Prognostic factors for the surgical management of peripheral nerve lesions: Tohoku J Exp Med 205:269-275, 2005

18. Dong Z, Zhang CG, Gu YD: Surgical outcome of phrenic nerve transfer to the anterior division of the upper trunk in treating brachial plexus avulsion. J Neurosurg 112:383-385, 2010

19. Gilbert A: Neurotization by contralateral pectoral nerve. Presented at the 10th Symposium on the brachial plexus, Lausanne, Switzerland, 1992

20. Gordon T, Brushart TM, Amirjani N, Chan KM: The potential of electrical stimulation to promote functional recovery after peripheral nerve injury-comparisons between rats and humans. Acta Neurochir 100:3-11, 2007

21. Havton LA, Carlstedt T: Repair and rehabilitation of plexus and root avulsions in animal models and patients. Curr Opin Neurol 22:570-574, 2009

22. Hentz VR, Doi K:Traumatic brachial plexus injury. In: Green DP, Hothkiss RN, Pederson WC, Wolfe SW (eds) Green's Operative Hand Surgery, 5th ed. Philadelphia: Elsevier and Churchill Livingstone, 2005:1319-1379

23. Jivan S, Kumar N, Wiberg M, Kay S: The influence of presurgical delay on functional outcome after reconstruction of brachial plexus injuries. J Plast Reconstr Aesthet Surg 62:472-479, 2009

24. Luedemann W, Hamm M, Blömer U, Samii M, Tatagiba M: Brachial plexus neurotization with donor phrenic nerves and its effect on pulmonary function. J Neurosurg 96:523-526, 2002 
25. Mackinnon SE, Novak CB, Myckatyn TM: Results of reinnervation of the biceps and brachialis muscles with a double fascicular transfer for elbow flexion. J Hand Surg (Am) 30:978-985, 2005

26. Malessy M, Ruiter G, de Boer K, Thomeer R: Evaluation of suprascapular nerve graft or transfer in the treatment of brachial plexus traction lesions. J Neurosurg 101:377-389, 2004

27. Merrel G, Barrie K, Katz D, Wolfe S, Haven N: Results of nerve transfer for restoration of shoulder and elbow flexion in the context of meta-analysis of the English literature. Hand Surg (Am) 26A:303-314, 2001

28. Merrell GA, Wolfe SW: Adult brachial plexus and thoracic outlet surgery. Tech Should Elb Surg 3:271-281, 2002

29. Millesi $\mathrm{H}$ : Coordinate function oriented movements after multiple root avulsion. Acta Neurochir 100:117-119, 2007

30. Oberlin C, Ameur NE, Teboul F, Beaulieu JY, Vacher C: Restoration of elbow flexion in brachial plexus injury by transfer of ulnar nerve fascicles to the nerve to the biceps muscle. Tech Hand Up Extrem Surg 6:86-90, 2002

31. Oberlin C, Beal D, Leechavengvongs S: Nerve transfer to biceps muscle using a part of ulnar nerve for C5-C6 avulsion of the brachial plexus: Anatomical study and report of four cases. J Hand Surg (Am) 19A:232-237, 1994

32. Rohde R S, Wolfe S W: Nerve Transfers for adult traumatic brachial plexus palsy (Brachial Plexus Nerve Transfer). HSSJ 3: 77-82, 2007

33. Samardzic M, Rasulic LG, Grujicic DM, Bacetic DT, Milicic BR: Nerve transfers using collateral branches of the brachial plexus as donors in patients with upper palsy thirty years' experience. Acta Neurochir 153:2009-2019, 2011

34. Secer HI, Solmaz I, Anik I, Izci Y, Duz B, Daneyemez KM, Gonul E: Surgical outcomes of the brachial plexus lesions caused by gunshot wounds in adults. J Brachial Plex Peripher Nerve Inj 4:11-17, 2009
35. Socolovsky M, Di Masi G, Battaglia D: Use of long autologous nerve grafts in brachial plexus reconstruction: Factors that affect the outcome Acta Neurochir 153:2231-2240, 2011

36. Songcharoen P: Management of brachial plexus injury in adults. Scand J Surg 97:317-323, 2008

37. Songcharoen P, Wongtrakul S, Spinner RJ: Brachial plexus injuries in the adult. Nerve transfers: The Siriraj Hospital experience. Hand Clin 21:83-89, 2005

38. Sungpet A, Suphachatwong C, Kawinwonggowit V: Transfer of a single fascicle from the ulnar nerve to the biceps muscle after avulsions of upper roots of the brachial plexus. J Hand Surg (Am) 25B:325-328, 2000

39. Suzuki K, Doi K, Hattori Y, Pagsaligan J: Long-term results of spinal accessory nerve transfer to the suprascapular nerve in upper-type paralysis of brachial plexus injury. J Reconstr Microsurg 23:295-299, 2007

40. Terzis JK, Papakonstanttinou K: The surgical treatment of brachial plexus injuries in adults. Plast Reconstr Surg 106:1097-1122, 2000

41. Terzis JK, Vekris MD, Soucacos PN: Brachial plexus root avulsions. World J Surg 25: 1049-1061, 2001

42. Terzis JK, Kostas I: Suprascapular nerve reconstruction in 118 cases of adult posttraumatic plexus. Plast Reconstr Surg 117:613-629, 2006

43. Venkatramani $H$, Bhardwaj $P$, Faruguee $R$, Sabapathy $R$ : Functional outcome of nerve transfer for shoulder and elbow function in upper brachial plexus injury. J Brachial Plex Peripher Nerve Inj 27:3-15, 2008

44. Weber RV, Mackinnon SE: Nerve transfers in the upper extremity. J Hand Surg (Am) 4:200-213, 2004

45. Yeoman PM, Seddon HJ: Brachial plexus injuries: Treatment of the flail arm. J Bone Joint Surg 43B:493-503, 1961

46. Zyaei A, Saied A: Functional outcome of ulnar nerve fascicle transfer for restoration of elbow. Xexion in upper brachial plexus injury. Eur J Orthop Surg Traumatol 20:293-297, 2010 